\title{
HOW IMPORTANT ARE FOREIGN BANKS IN THE FINANCIAL DEVELOPMENT OF EUROPEAN TRANSITION COUNTRIES?
}

\author{
ILKO NAABORG \\ BERT SCHOLTENS \\ JAKOB DE HAAN \\ HANNEKE BOL \\ RALPH DE HAAS
}

CESIFO WORKING PAPER NO. 1100

CATEGORY 6: Monetary Policy and INTERNATIONAL FinANCE

DECEMBER 2003

\footnotetext{
An electronic version of the paper may be downloaded

- from the SSRN website:

- from the CESifo website:

www.SSRN.com

www.CESifo.de
} 


\title{
HOW IMPORTANT ARE FOREIGN BANKS IN THE FINANCIAL DEVELOPMENT OF EUROPEAN TRANSITION COUNTRIES?
}

\begin{abstract}
This paper analyzes the development of the banking sector in European transition countries. We find that, although bank assets increased during the $1990 \mathrm{~s}$, credit to the private sector remained relatively low. Foreign-owned banks have become major players in the financial system of these countries. However, foreign bank presence and financial development in general vary considerably among the transition economies. Foreign-owned banks have, in general, higher profitability levels than domestic banks. Furthermore, it appears that foreign and domestic bank performance tend to converge.
\end{abstract}

JEL Classification: F36, G15, G20, O16, P34.

Keywords: financial development, financial institutions, foreign bank entry, transition economies, bank performance.

Ilko Naaborg, Bert Scholtens, Hanneke Bol

University of Groningen

Faculty of Economics

P.O. Box 800

9700 AV Groningen

The Netherlands

I.J.Naaborg@ECO.RUG.NL

\author{
Jakob de Haan \\ University of Groningen \\ Faculty of Economics \\ P.O. Box 800 \\ 9700 AV Groningen \\ The Netherlands
}

\author{
Ralph de Haas \\ The Netherlands Bank \\ Research Department \\ P.O. Box 98 \\ 1000 AB Amsterdam \\ The Netherlands
}

This research was financed by the European Union as ACE project P98-1082R. Part of this research was done while De Haan was visiting scholar at the Netherlands Bank. We like to thank all participants of this project for their help and their stimulating comments on conferences in Tallinn, Poznan, and Groningen. Moreover, we like to thank representatives of the Central Banks of Croatia, the Czech Republic, Estonia, Hungary, Latvia, Lithuania, Poland, Romania, the Slovak Republic and Slovenia as well as the ATPF of Hungary who provided data. We also like to thank Lusine Lusinyan and two anonymous referees for their useful comments. 


\section{Introduction}

There is a growing interest in the impact of foreign banking on the financial system and the economic development of emerging and transition countries (Claessens, Demirgüç-Kunt and Huizinga, 2001; Iakova and Wagner 2001; Mathieson and Roldos 2001). The upcoming eastward enlargement of the European Union has only increased this interest. During the past decade, many former communist countries have made substantial progress in the transition from a centrally planned economy to a market based economy. In recent years, progress has been particularly significant in restructuring and consolidating the banking sector. This has mainly been accomplished through the privatization of state-owned banks and the opening-up of the banking sector to foreign ownership.

This paper analyzes the development of the banking sector during the transition process in the Central and Eastern European countries. We particularly focus on the position of foreign-owned banks, as it turns out that they play an important role in the development of the financial system of European transition countries: more than half of the banks in the region are foreign-owned, accounting for two thirds of total bank assets. We have gathered new data about several aspects of the development, structure, conduct and performance of the banking sector in the region. As such, this paper is one of the first to analyze the complete region on the basis of an identical methodology for all countries. ${ }^{1}$

Our analysis is based on a number of key indicators, summarized in Appendix 1. We use definitions in line with those proposed by Beck, Demirgüç-Kunt and Levine (1999). We define a bank to be foreign in case

\footnotetext{
${ }^{1}$ Up to now, most studies focused on a limited number of countries within the region. For example, Dobosiewicz (1995), Mervart (1996), Sabi (1996), Buch (1997), Steinherr (1997), Bonin, Mizsei, Székely and Wachtel (1998), Bonin and Abel (2000), Galac and Kraft (2000), Hasan and Marton (2000), Scholtens (2000), Storf (2000), Barisitz (2001), Schardax and Reiniger (2001). For a comprehensive overview of the financial sector in transition countries in 2001, see ECB (2002).
} 
more than 50 percent of its shares are owned by foreigners. Of course, banks from outside the country may have a minority share so that focusing on the number of banks owned by foreign banks may underestimate foreign influence. Therefore, we also take in consideration the development of foreign-owned bank assets.

A problem in analyzing the transition process is the lack of reliable data. Therefore, we have sought the co-operation of central banks in the region. Several central banks helped us to gather aggregated data required to analyze the development of the banking sector and the role of foreign banks. This information was supplemented with data from the IMF's International Financial Statistics and data from the EBRD. However, for a good understanding of the banking sector in the transition economies, adequate knowledge of the operations of individual banks is essential. Data on individual banks were therefore gathered using the BankScope database.

Our main findings are that the speed of financial development has been rather slow in the transition countries. Foreign-owned banks have become major players in the financial system of Central and EasternEuropean countries. However, financial development and foreign bank presence vary considerably among the transition economies. Although bank assets increased during the $1990 \mathrm{~s}$, credit to the private sector remained relatively low. Foreign-owned banks lend more to the private sector than domestic banks. They have, in general, also higher profitability levels than domestic banks. However, it also appears that the performance of foreign and domestic banks tend to converge.

The structure of the paper is as follows. The following section points out some basic features of the financial system in the transition economies. We focus on the intermediation role of the banking sector in the selected transition economies and make a comparison with the euro area. Section 2 examines the degree of foreign bank penetration in transition economies. Trends in the number of foreign-owned banks and their assets will be discussed. This will give us an idea about the importance of their 
presence. Section 3 analyzes the background and key characteristics of foreign-owned banks. Section 4 compares the activities of foreign and domestic banks. Section 5 evaluates bank performance in the European transition countries, focusing on profitability and efficiency of domestic and foreign banks. Section 6 concludes.

\section{Intermediation}

Figure 1 shows the development of the average assets of deposit money banks as a ratio to GDP in Central and Eastern European (CEE) countries and the euro area, while figure 2 presents figures for individual countries in the year 2000. The ratio between banks assets and GDP illustrates the importance of the financial services provided by banks relative to the size of the economy (Beck et al., 1999). In general, the average of deposit money bank assets to GDP in the euro area is at least twice as high as in the transition countries.

Figure 1. Deposit money banks assets and private sector credit in CEE countries and the euro area (\% GDP), 1993-2000

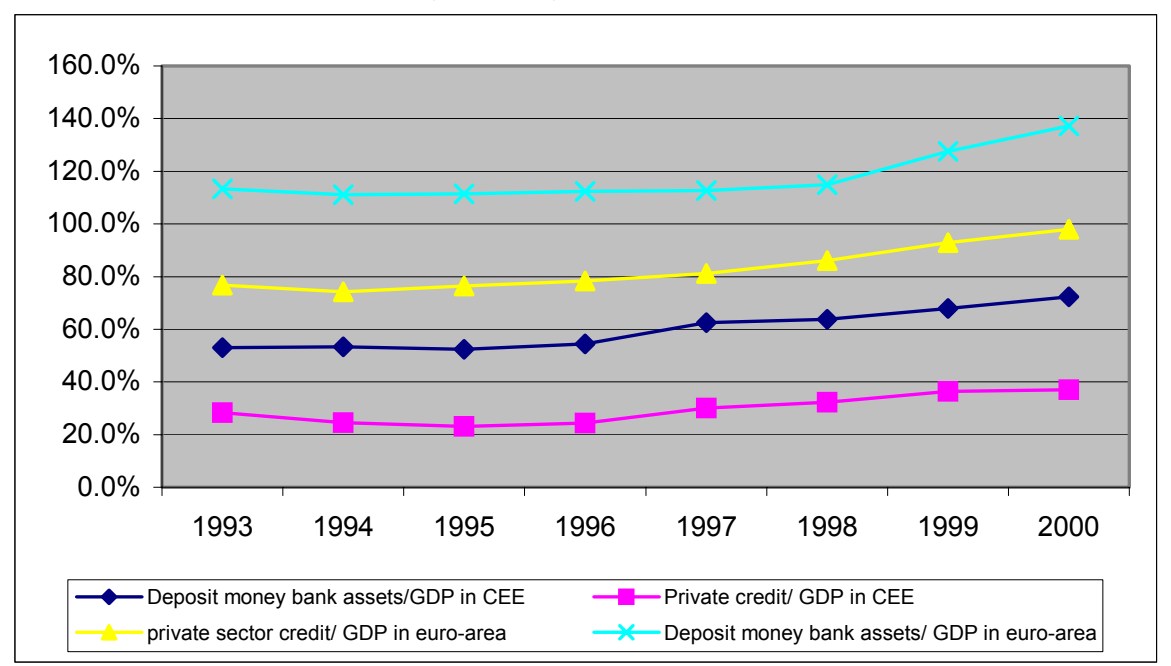

Source: Central banks of Croatia, the Czech Republic, Estonia, Hungary, Latvia, Lithuania, Poland, Romania, the Slovak Republic, Slovenia and IMF for euro area (excl. Luxembourg). 
Figure 2. Bank claims on the public and the private sector in CEE countries and the euro area (\% GDP), 2000

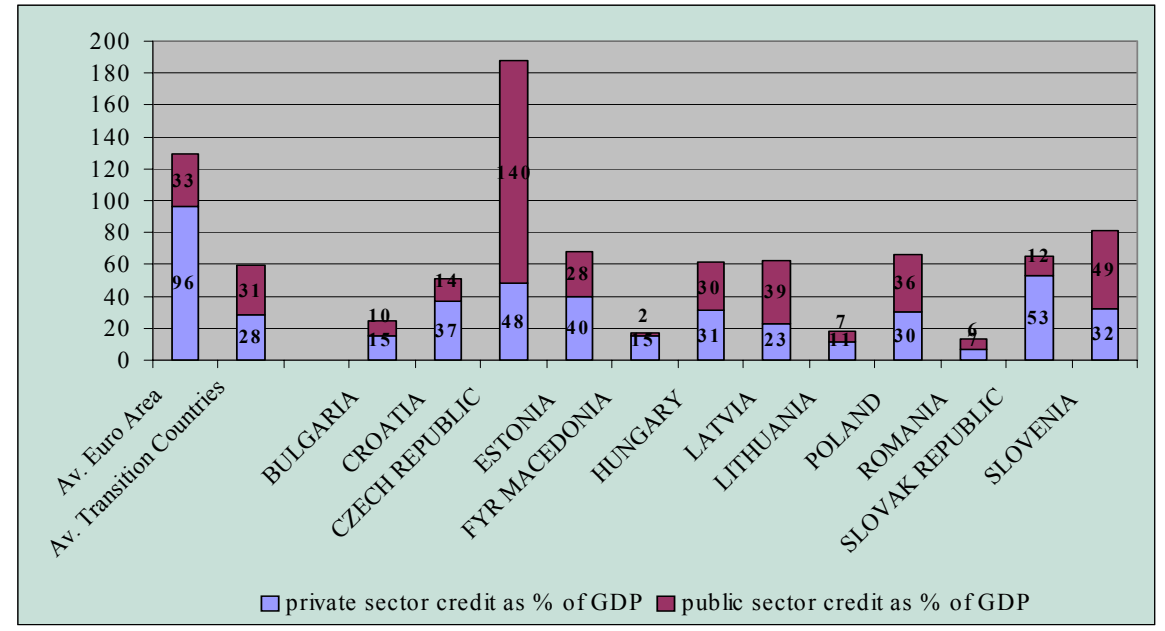

Source: Central Banks and IMF for Bulgaria, Lithuania, Macedonia, Romania and euro area.

The European transition economies show no uniform pattern of financial development. Bank assets in relation to GDP is by far highest in the Czech Republic (see figure 2). This is the only European transition economy with a financial sector size similar to that of the euro area. In Estonia, Hungary, Latvia, Poland, the Slovak Republic and Slovenia bank assets amount to more than $60 \%$ of GDP in 2000 and this ratio has been moving upward in the recent past. Croatian banks have assets that amount to about $50 \%$ of GDP. Banking sectors are smallest in Bulgaria, Lithuania, Macedonia and Romania. In these countries, this key ratio has even been subject to a downward trend.

Figures 1 and 2 also present the level of bank claims on the private sector as share of GDP. This ratio shows the importance of one of the main functions of financial intermediaries, i.e. channeling funds to investors. Private credit captures the loans to the private non-financial sector (Beck et al., 1999). The difference with total deposit money bank assets mainly consists of claims on the government and on (semi-)public enterprises. Figure 1 shows that credit to the private sector increased in CEE countries but to a lesser extent than total deposit money bank assets. In the euro area, 
private credit is about three times as high as public credit, whereas in the transition countries private and public credit have about the same size. Still, major differences exist between the various CEE countries with respect to bank lending to the private sector, as figure 2 illustrates. In the Czech Republic, Estonia, and the Slovak Republic the ratio of private sector credit to GDP is $40 \%$ or higher. In Croatia, Hungary, Poland and Slovenia the ratio is between $30 \%$ and $40 \%$, whereas it is less than $30 \%$ in the other transition countries.

Two opposing forces may have influenced extending private credit in the transition economies. First, more developed countries generally have more developed financial markets (see Khan and Senhadji, 2000). So, one would expect that economic development in a transition country will lead to more credit to the private sector. Due to relatively underdeveloped equity markets in transition economies, firms in need of external funds depend on bank credit. Second, due to poor conditions in the banking sector credit to the private sector may, however, stagnate. Banks have started to invest more in liquid securities such as government bonds (De Haas, 2002).

Figure 3. Private sector credit as share of total credit in CEE countries, annual average and standard deviation, 1993-2000

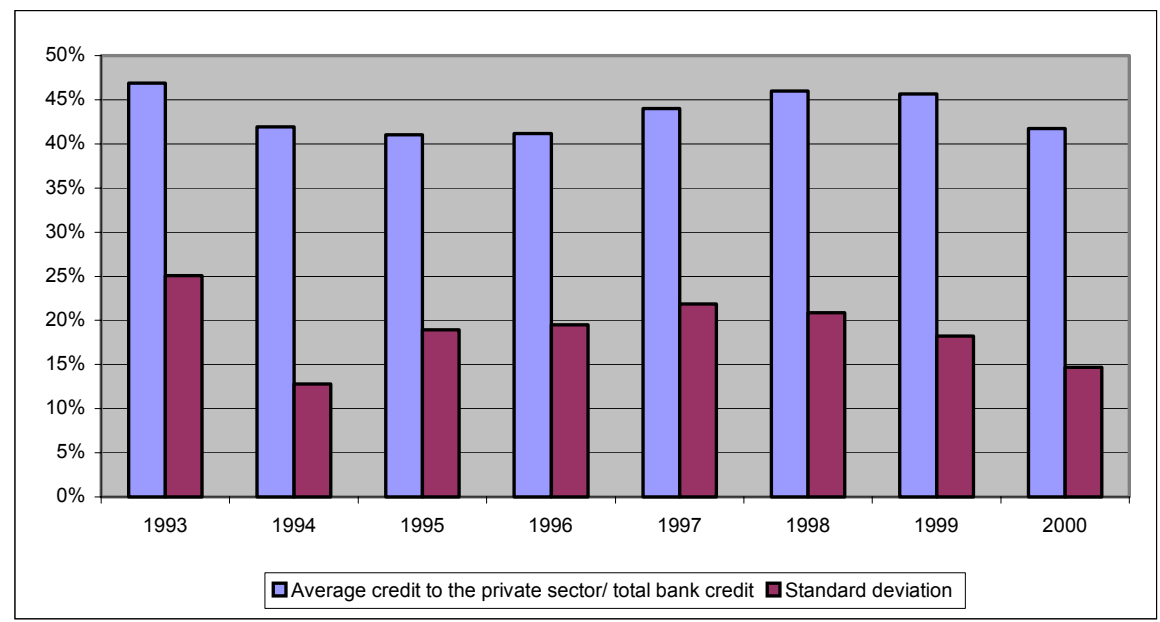

Source: Central banks of Croatia, the Czech Republic, Estonia, Hungary, Latvia, Lithuania, Poland and Slovenia. 
According to De Haas and Van Lelyveld (2002), the reluctance of banks to grant new loans to the private sector partly results from lengthy legal procedures, especially the inadequate enforcement of creditor rights. Indeed, as follows from figure 3 , the average share of credit to the private sector as share of total credit in CEE countries hovers around $40-45 \%$ in the period 1993-2000. The standard deviation of this indicator fell from $25 \%$ in 1993 to around $15 \%$ in 2000 , suggesting that the CEE countries have become more similar in this respect.

The literature on finance and economic development (see King and Levine, 1993a,b; Levine, 1997; Khan and Senhadji, 2000; Levine, Loayza and Beck, 2000) suggests that bank activities increases in income. Figure 4 plots the private credit/GDP ratio and per capita income in eleven transition countries for the year 2000. It appears that there is a positive association between credit to the private sector and per capita income in the transition economies. The outlier is Slovenia with a relative high level of per capita income. $^{2}$

Figure 4. Private sector bank credit/GDP and per capita income (USD) in CEE countries, 2000

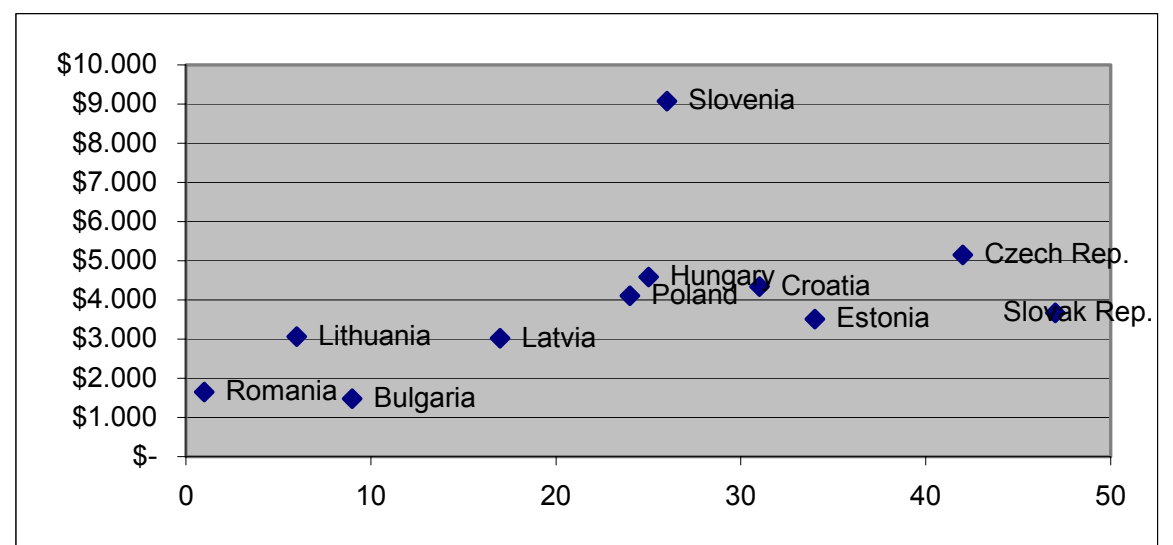

Source: Central banks for private credit/GDP (IMF for Bulgaria and Romania) and EBRD for per capita income.

${ }^{2}$ A simple trend regression confirms this observation. We define GDPPC as per capita GDP and PRIVCRG as private credit to GDP. The simple regression result is: PRIVCRG $=16,77+0.00329$ GDPPC (p-value is $0.15 ; \mathrm{R}^{2}=0.21$ ). 
This brief overview reveals that the transition economies differ substantially with respect to the development of the banking sector. The Czech Republic, Croatia, the Slovak Republic and Slovenia have the most developed banking systems, while Bulgaria, Macedonia, and Romania lag behind. There appears to be a positive association between the level of financial and economic development for most countries in the year 2000 . As far as financial development is concerned, there is a great discrepancy between the transition countries and the euro area with respect to the level and composition of financial intermediation.

\section{Foreign bank presence}

The increasing foreign bank presence since the 1990s is one of the most striking developments in the banking system in the transition economies. We find that, on average, foreign-owned banks account for more than half of the total number of banks in 2000 and hold more than two thirds of total bank assets in most transition economies. However, the importance of foreign banks varies a lot among countries. Still, foreign bank presence in all transition countries is considerably higher than in the European Union countries, with the exception of Luxembourg (Claessens et al., 2001; Noyer, 2001).

Figure 5 illustrates the development of the relative number of foreign and domestic banks in CEE countries for the period 1995-2000, while Appendix 2.1 gives the absolute number of foreign banks for the individual countries. In 1995, 113 foreign banks were present in the countries in our sample, accounting for almost $30 \%$ of total banks. In 2000 , their number had risen to 202 , accounting for more than $60 \%$ of all banks. In particular in Croatia, Hungary, Lithuania, Poland, Romania the number of foreign banks grew very strongly. In Latvia, the Slovak Republic and 
Slovenia the number of foreign banks is in 2000 about the same as in the first year of observation.

Figure 5. Number of banks and total bank assets in CEE countries: foreign versus domestic, $1995-2000(\%)$

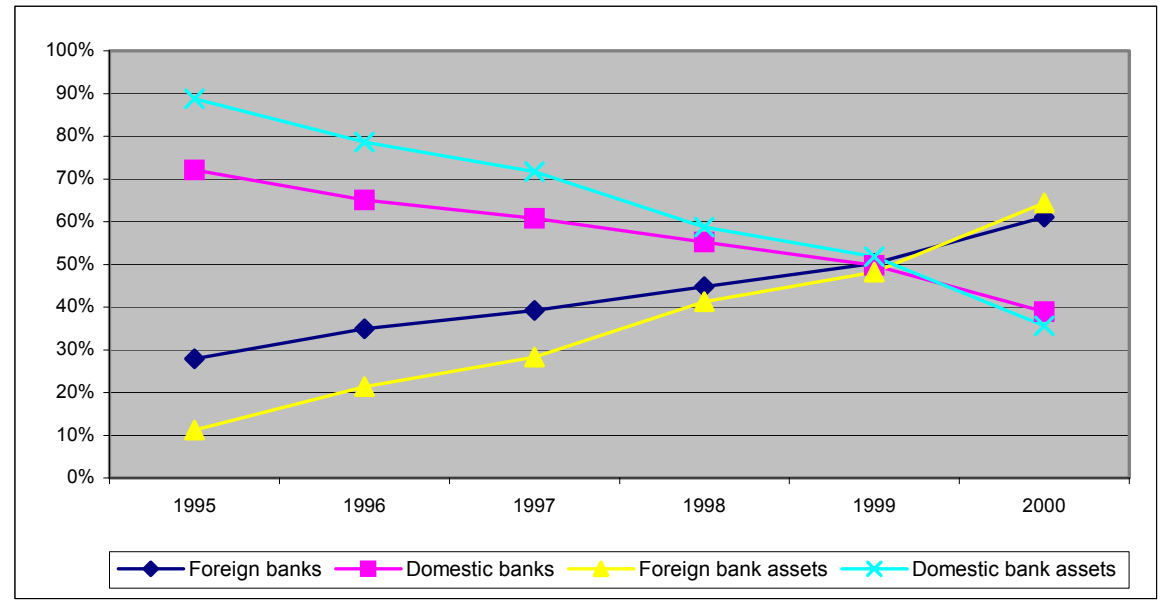

Source: Foreign and domestic banks: Central banks of Croatia, the Czech Republic, Estonia, Hungary, Latvia, Lithuania, Poland, Romania, the Slovak Republic, Slovenia. Relative amount of foreign and domestic banks assets: idem minus Romania.

Figure 5 also shows foreign banks assets as a percentage of total banks assets in CEE countries, while Appendix 2.2 gives the figures for the individual countries. It appears that foreign bank participation increased considerably during the second half of the 1990s. At the end of the decade, the share of banking assets under foreign control had reached around 64\%. After several banking crises hit most transition countries in the mid-1990s (see Caprio and Klingebiel (2002) for an overview of the different crises), bank privatization furthered foreign participation. Initially, most sales involved medium-sized banks. Later on, the larger state-owned saving banks were sold too. For example, in Estonia, the first foreign-owned bank was already established in 1992. But only in 1998 the share of foreign bank assets rose to $90 \%$. During the same period, the number of foreign banks as share of the total number of banks in Estonia increased from $8 \%$ to $50 \%$, 
reflecting that the two largest banks (Hansa Bank and Eesti Uhispank) were sold to foreign banks in 1998 (EBRD, 2001).

\section{Foreign bank characteristics}

So far, our analysis has been based on aggregated data mainly provided by national central banks (see part A of Appendix 1). In order to analyze characteristics of individual banks (like the origin of foreign banks and their entry strategy) we use the BankScope database (see part B of Appendix 1). ${ }^{3}$ BankScope provides balance sheet data and profit and loss accounts for individual banks, adjusting individual bank accounts for differences in reporting and accounting standards. Our sample is taken from the September 2001 version with data for the period 1991-2000.

Three problems arise when using BankScope. Firstly, BankScope contains banks not being active on the market anymore due to bankruptcy, take-over or a merger. Secondly, BankScope does not contain all banks active on the market. Thirdly, BankScope does not capture foreign branches; this can lead to an underestimation of the level of foreign participation.

These problems differ in weight for the specific countries. To deal with these problems and making the BankScope database more reliable and useful, the background of every bank has been checked using the homepages of the banks or by having email contact with the bank. BankScope provides balance sheet data and profit and loss accounts. We have added the following information: the year of establishment of the bank, whether the bank is foreign or not, the year the bank became foreign, whether it was a greenfield investment and, finally, the country of origin of

\footnotetext{
${ }^{3}$ From Appendix 3, it appears that the aggregated data base and the extended BankScope data set are quite similar, although some small differences remain, in particular for the Czech and Slovak Republics. Part of the difference is due to differences in the definition of a bank. For the aggregated data base we use the definition of a bank of Beck et al. (1999). Consequently, the aggregated data base does not contain saving banks, cooperative banks, mortgage banks and building societies. The classification 'commercial banks', which is used in BankScope, is not exactly the same.
} 
the foreign owner. Furthermore, banks active on the market but not recorded in BankScope and foreign branches have been detected and added to the database, using the homepages of the specific banks.

With respect to the characteristics of the foreign banks in the CEE countries, we may summarize our findings as follows. The three largest banks in each European transition economy are, with a few exceptions, in foreign hands. Table 1 gives the nationality of the owner of the largest three banks in each country in October 2000. There is a relatively strong presence of neighboring countries in some of the European transition economies. For example, in the Baltic countries Swedish banks (in most cases Hansabank) own the big banks. Austrian banks are well represented in the Slovak Republic and Croatia. Many Italian banks have been established in Croatia. Banks from non-European countries are almost absent in the transition countries, the US-based Citibank and GE Capital being the exceptions. In 2000 in Croatia, Hungary, Slovenia and Romania the largest bank was still owned by the government or it was a local private bank.

Table 1. Ownership of the largest three banks as of October 2000.

\begin{tabular}{llll} 
& No. 1 & No. 2 & No. 3 \\
\hline Estonia & Sweden & Sweden & Finland \\
Latvia & $\begin{array}{l}\text { Domestic } \\
\text { Lithuania }\end{array}$ & Sweden & Domestic \\
& Sweden & Sweden & Domestic \\
Croatia & State & Italy & Luxembourg \\
Romania & State & France & Turkey \\
& & & \\
Czech Republic & Belgium & Austria & France \\
Hungary & Domestic & Belgium & Germany \\
Poland & Italy & US & Ireland \\
Slovakia & Italy & Austria & Austria \\
Slovenia & State & State & France \\
\hline Source: BankScope & & &
\end{tabular}


The number of greenfield investments is around $40 \%$ of the total number of foreign banks. Furthermore, the number of banks with less than 50\% foreign participation has decreased over time. The most frequently used mode of entry of foreign banks is that the foreign bank initially buys a small part of a domestic bank. Over time, this share is expanded until a majority of the shares is acquired. This approach may be regarded as typical for expansion into the transition countries. It contains aspects of a greenfield investment and of an acquisition (as the bank regains control over an already existing institution). Also, in some countries, buying an existing bank means getting around restrictions concerning greenfields. For example, in Poland foreign banks were required, in most cases, to take over existing troubled Polish banks in order to obtain licenses (EBRD, 1998).

When a foreign-owned bank buys a domestic bank in a transition country, the newly bought bank usually keeps its original name. On average, only about $30 \%$ of the acquired banks uses the name of the foreign acquirer. However, we witness that this practice varies from country to country. For example, in Hungary most banks bought by a foreign bank get a new name. In Bulgaria, however, banks usually continue to operate under their original name.

\section{Activities of domestic versus foreign banks}

There are various motives for banks to go abroad and various determinants are involved in foreign banking (see Scholtens, 1992). One of the main reasons for foreign expansion is that foreign banks follow their customers (Goldberg and Saunders, 1991; Brealey and Kaplanis, 1996; Konopielko, 1999; Buch, 2000; Moshirian, 2001; Green, Murinde and Nikolov, 2002; Lensink and Hermes, 2002; Williams 2002). However, Seth, Nolle and Mohanty (1998) find that foreign-owned banks first and foremost lend to borrowers other than customers from the home nation. Du (2003) finds that foreign subsidiaries of multinational enterprises have incentives to borrow 
from local, in particular domestic, banks, rather than from the parent's bank. The main reason, according to $\mathrm{Du}$ (2003), is that bank co-financing with local participation hardens the budget constraint because local banks have strength in seizing firm assets in liquidation. Stanley, Roger and McManis (1998) mention that foreign banks tend to have high proportions of their assets invested in loans to domestic borrowers. Berger, Klapper and Udell (2001) and Clarke, Cull and Martinez-Peria (2001) find that foreign banks have problems supplying funds to small businesses. Once established abroad, foreign banks focus their activities mainly on large enterprises.

The activities of foreign banks are also dependent on the mode of entry. A take-over goes along with the acquisition of the existing client base, including its retail banking activities. Along with the greenfield investment goes the ability to build up the activities from scratch. The bank does not have to cope with the potential of a bad loans portfolio from past activities. Regulation may also affect the activities of foreign banks. In Slovenia, for example, liberalization of foreign borrowing by residents and the abolition of interest rate ceilings on deposits have created a more competitive environment, but only since 1999 (EBRD, 2001). Likewise, Hungary initially did not permit banks to provide financial and insurance services. Changed legislation in 1999 resulted in a movement towards a model of universal banking (ECB, 2001).

We investigate what role foreign banks play in extending credit to the private and the public sector in comparison with domestic banks. Figure 6 shows the development of the average volume of credit to the private and public sector as share of total bank credit over the period 1993-2000 both by domestic and foreign banks. It is clear that domestic banks have been replaced by foreign banks as creditors. In 1993, domestic banks were the primary source of credit for the public and the private sector, while in 2000 foreign banks dominate both markets. Credit to the public sector exceeds credit to the private sector for domestic as well as for foreign banks. We find that the huge amount of credit to the public sector in the Czech 
Republic influences the two averages for the foreign banks to a great extent. With the Czech Republic not taken into account, credit to the private sector by foreign banks would exceed credit to the public sector as from 1998 . Leaving out the Czech Republic hardly has any effect for the trend in credit supply by domestic banks; they still lend primarily to the public sector.

Figure 6. Credit supply of domestic and foreign banks as share (\%) of total bank credit in CEE countries, 1993-2000

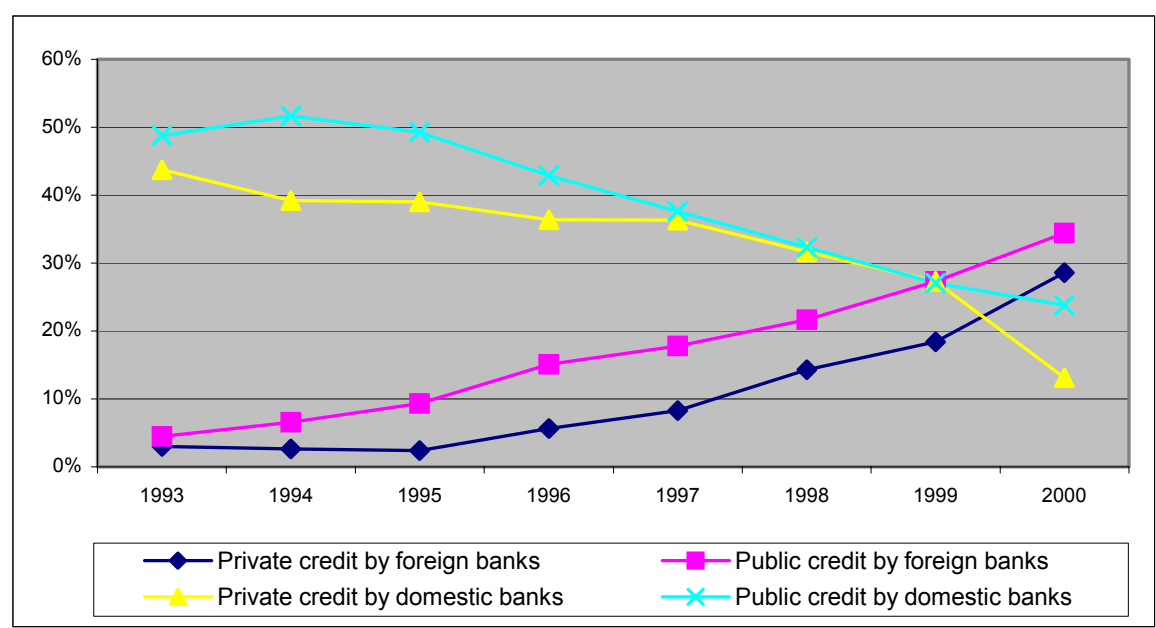

Source: Central banks of Croatia, the Czech Republic, Estonia, Hungary, Latvia, Lithuania, Poland and Slovenia.

Figure 7. Credit to the private sector as share of total bank credit: domestic vs. foreign banks, 2000

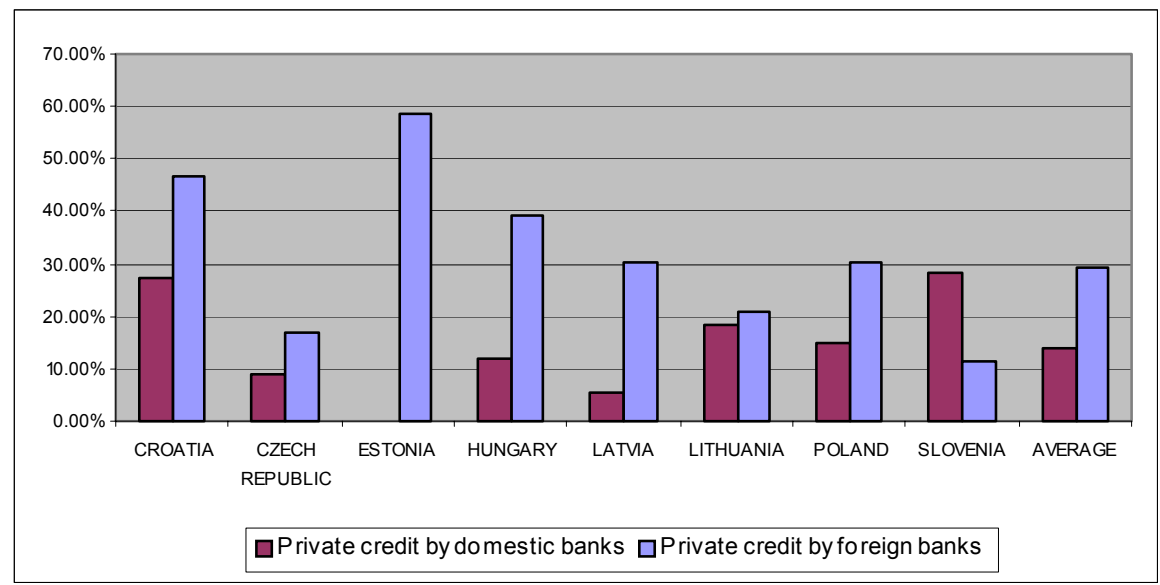

Source: Central banks of Croatia, the Czech Republic, Estonia, Hungary, Latvia, Lithuania, Poland and Slovenia. 
As can be observed from Figure 7, foreign banks in all transition countries, except for Slovenia, appear to be more involved with lending to the private sector than domestic banks. Still, there are substantial differences among the transition countries as to the relative importance of private lending by foreign banks. The most extreme case is Estonia, where domestic banks hardly provide credit to the private sector.

\section{Performance}

According to Claessens et al. (2001), foreign banks are more profitable and efficient than domestic banks in developing countries, while in developed countries domestic banks are more profitable and efficient than foreign banks. These differences can reflect a differential impact of informational (dis)advantages, customer bases, bank procedures as well as different relevant regulatory and tax regimes. In contrast, DeYoung and Nolle (1996) and Berger, DeYoung, Genay and Udell (2000) find that foreign banks are less efficient than host nation banks in developed nations. Berger, Dai, Ongena and Smith (2003) find that foreign affiliates of multinational firms use host nation banks for cash management services. This choice appears to affect the geographic scope and size of the chosen bank, the so-called bank reach. Furthermore, they find that legal and financial development of the host nation affect both bank nationality and bank reach. Focarelli and Pozzolo (2001) and Buch and DeLong (2001) analyze cross-border M\&A in the banking industry. These, in general, appear to be relatively unprofitable (see also Berger et al., 2000; DeLong, 2001).

There are only few studies on the profitability and efficiency of the banking sector in the transition economies. Green et al. (2002) estimate the efficiency of domestic and foreign banks in Central and Eastern Europe, in terms of economies of scale and scope. They find that foreign banks are not really different from domestic banks and that bank ownership (foreign versus domestic) is not an important factor in reducing bank costs. Kraft 
and Tirtiroglu (1998) have studied X-efficiency and scale-efficiencies for both old and new (state and private) banks in Croatia. New banks (i.e. foreign banks) are shown to be more $\mathrm{X}$-inefficient and more scaleinefficient than either old privatized banks or old state banks. However, new private banks are highly profitable. According to these authors, this abnormal situation has been the result of free-riding opportunities created by distressed borrowers, limited competition and start-up difficulties of the new banks. Yildirim and Philippatos (2002) find that foreign banks in transition countries are more cost efficient but less profit efficient relative to domestic banks. Zajc (2002) finds for six European transition countries that foreign bank entry reduces net-interest income and profit, and increases costs of domestic banks.

To examine to what extent foreign banks are more efficient and profitable in transition countries, we investigate a number of indicators at the aggregate level for both foreign and domestic banks: the return on assets (ROA), after tax income, net interest margin, and overhead costs. ${ }^{4}$ The first indicators reflect banks' profitability, the third indicator signals credit market efficiency, and the final one reflects operational efficiency of the banks.

Figure 8 gives the average ROA for foreign and domestic banks ${ }^{5}$. It appears that the average ROA of foreign banks is higher than the average ROA of the domestic banks. The picture is severely affected by bad results for domestic banks in 1998 and 1999. In all other years, the ROA of domestic banks did not diverge much from that of foreign banks.

The ROA of foreign banks in Croatia sharply increased since its opening up to foreign banks. In Romania and Hungary, the foreign banks' ROA fell in the period under consideration. Estonian domestic banks had a

\footnotetext{
${ }^{4}$ The data about foreign and domestic bank performance in individual countries are available upon request.

${ }^{5}$ Unfortunately, we do not have access to reliable information in order to adjust these data for risk.
} 
particular bad year in 1998 when their combined ROA was $-24 \%$. Without Estonian banks, domestic banks' ROA in transition countries would have been $-1.5 \%$ instead of $-4.3 \%$. Figure 8 shows that the ROA of domestic banks tends to converge to the average ROA level of foreign banks. The general conclusion can be that both for domestic and for foreign banks there is an upward trend in ROA, while domestic banks were more sensitive to the economic and financial crisis in 1998 (moratorium from the Russian debt crisis) than foreign banks.

Figure 8. Return on assets of banks in CEE countries: foreign vs. domestic banks, 1995-2000

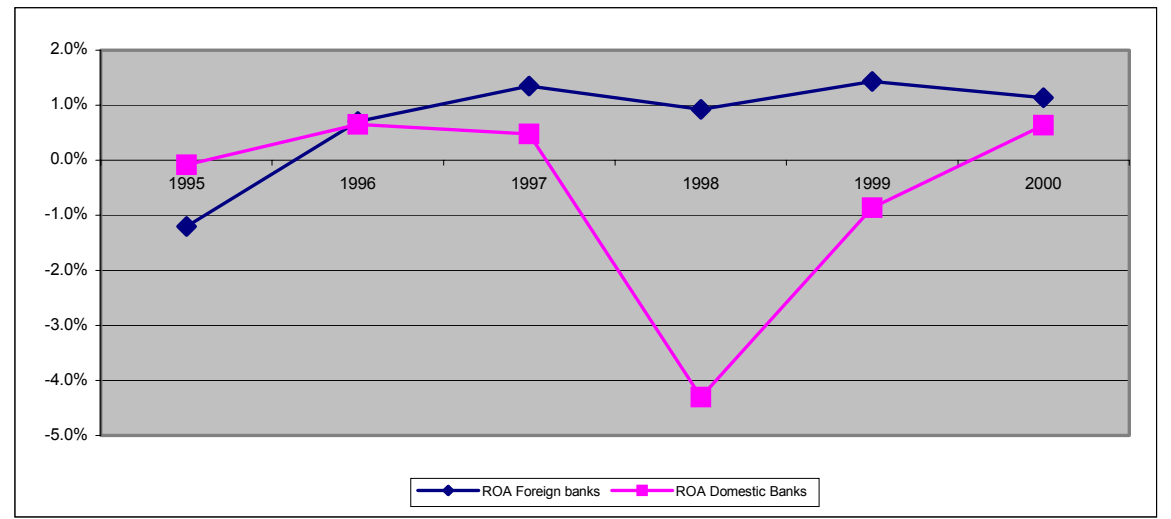

Source: Central banks of Croatia, the Czech Republic, Estonia, Hungary, Lithuania, Romania, the Slovak Republic and Slovenia.

The pattern for after tax income of domestic and foreign banks differs substantially from that of the aforementioned performance indicator. Domestic and foreign banks are subject to contrasting developments in their after-tax income (see figure 9). As foreign banks initially experienced a decreasing after tax-income, after 1997 their after tax income followed an upward trend. Domestic banks however generate lower income every year since 1997. Both foreign and domestic banks generate a low after-tax income in Croatia and Estonia. In contrast, after tax income is relatively high in the Czech Republic, Hungary and Slovenia. 
Figure 10 reveals that the interest margin of domestic banks is higher than that of foreign banks. Interest margin is defined as banks net interest income as a share of its total assets. With respect to this performance indicator, domestic and foreign banks appear to move closely together after 1998, but in 2000, they seem to diverge. The Czech Republic witnessed the lowest margins for its domestic banks. Croatia and Estonia had, especially during the late 1990s, a high margin, both for their domestic and foreign banks.

Figure 9. After-tax income of banks in CEE countries: foreign vs. domestic banks, 1995-2000

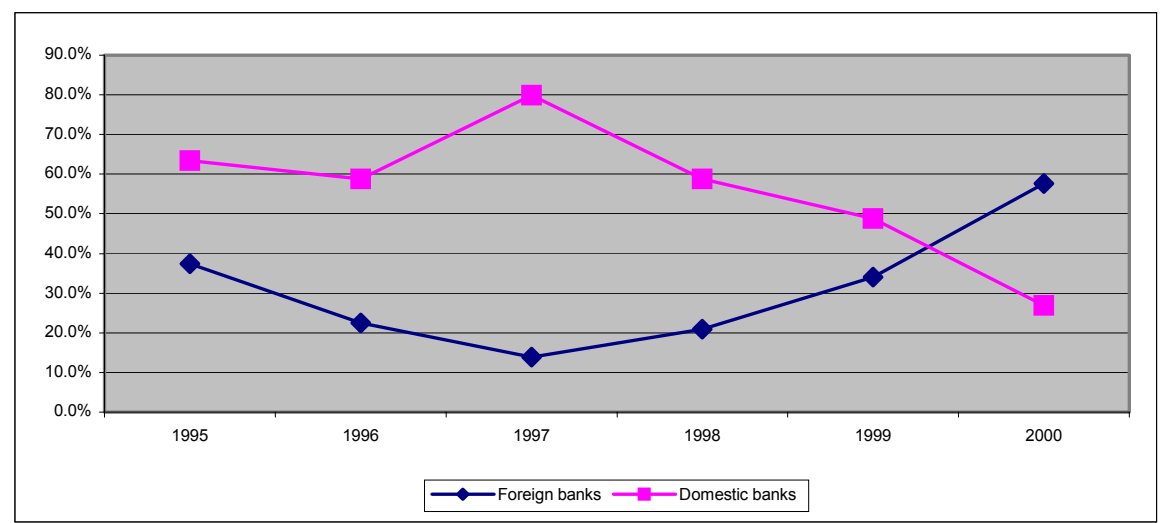

Source: Central banks of Croatia, the Czech Republic, Estonia, Hungary, Lithuania, Poland, the Slovak Republic, Slovenia.

Figure 10. Average interest margin in CEE countries: domestic vs. foreign banks, 1995-2000

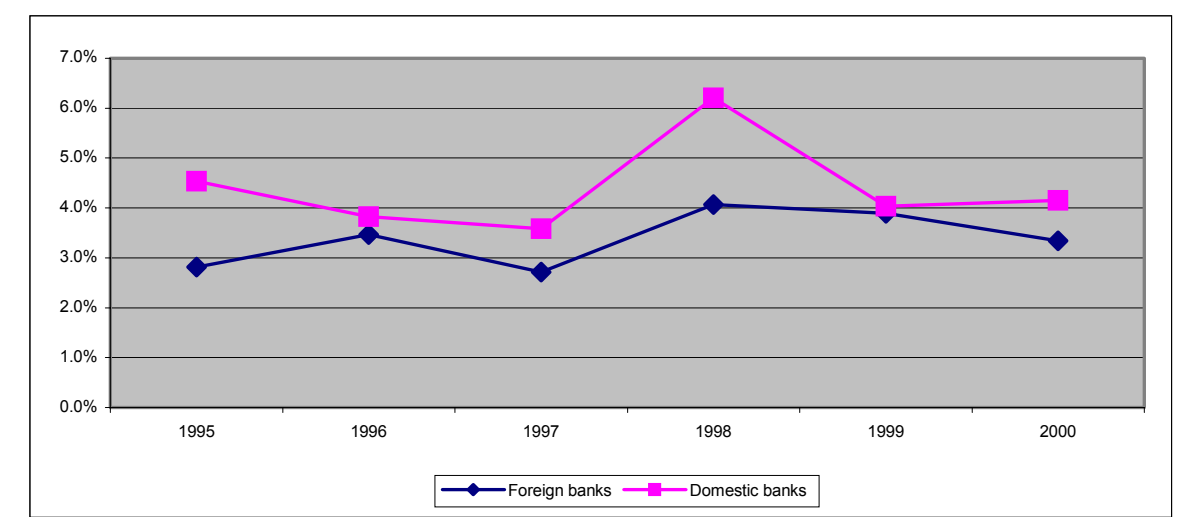

Source: Central banks of Croatia, the Czech Republic, Estonia, Hungary, Lithuania, the Slovak Republic. 
Claessens et al. (2001) and Kraft and Tirtiroglu (1998) conclude that foreign banks are more profitable than domestic banks in transition economies. Our results broadly confirm these findings, but they also show that foreign banks need some time before they outperform domestic banks.

A stylized fact from the economic literature as referred to above is that the costs of foreign banks are lower than those of domestic banks. However, for the transition countries, figure 11 reveals that the differences between domestic and foreign banks in the overhead costs as percentage of the total assets are rather small. In addition, one can observe the downward trend for both domestic and foreign banks. In the Czech Republic, the costs of domestic banks are even lower than the costs of most foreign banks in other countries. However, the foreign banks in the Czech Republic also have a lower cost level than the domestic ones. Estonia and Lithuania show a strong decrease in costs of domestic banks during the second part of the nineties. According to Lensink and Hermes (2002), the costs of domestic banks in developing countries rise with foreign bank entry. We cannot confirm their conclusion for the transition economies.

Figure 11. Average non-interest costs of banks in CEE countries: domestic vs. foreign banks, 1995-2000

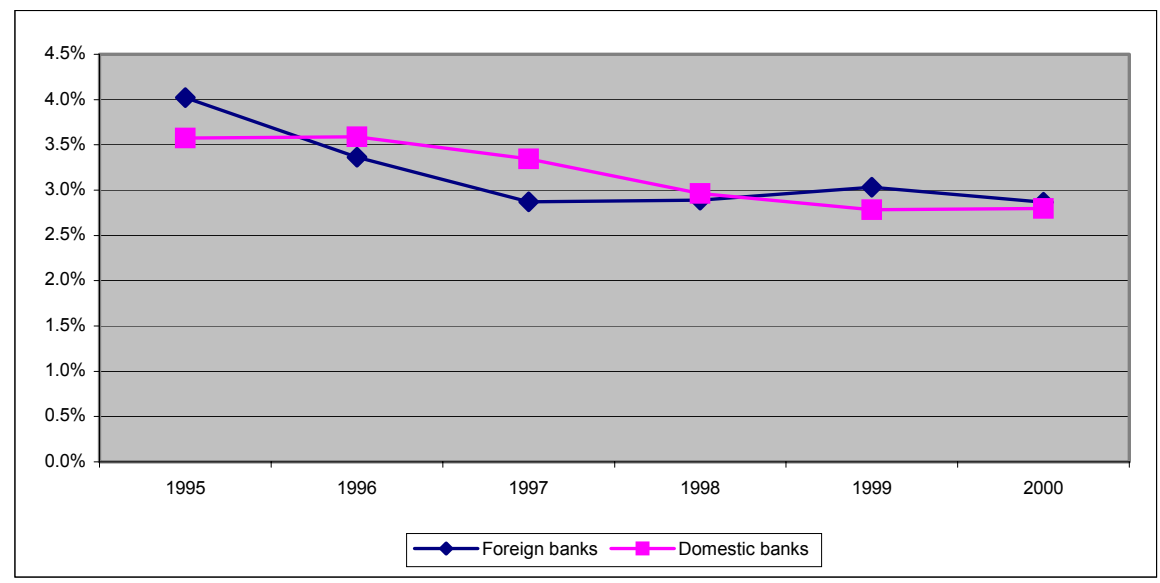

Source: Central banks of Croatia, the Czech Republic, Estonia, Hungary, Lithuania, the Slovak Republic, Slovenia. 
In sum, we find that foreign banks in the transition economies generally outperform domestic banks in terms of bank profitability. However, we also find that most performance indicators converge in the late 1990s.

\section{Concluding comments}

Foreign bank entry has been one of the most striking features of the development of the banking system in the European transition economies. At present, more than half the number of banks in the transition economies is foreign-owned and foreign-owned banks possess two thirds of total bank assets. This 'takeover' occurred within a period of less than ten years. However, the speed of financial development has been rather slow in the transition countries, in particular the level of credit to the private sector. In the early years of transition, foreign banks established representative offices and took minority interests in domestic banks. It appears that geographical relatedness has been an important factor as far as the choice of the country of entry is concerned. From the mid-1990s onwards, foreign banks established greenfields and took minority interests in domestic banks. They gradually increased these interests and were active buyers of stakes in privatized banks. Ultimately, this has resulted in a substantial number of majority interests of foreign banks.

Whether the extensive involvement of foreign banks has been beneficial to European transition countries is hard to say. According to our analysis up to 2000 , the general level of financial development, e.g. the level of total claims in the banking system as percentage of GDP, has increased only moderately. In addition, the composition of the financial structure did not change much: credit supplied to the private sector rose only moderately. Foreign banks contributed to this development only in that they took over the role as creditor. Although foreign banks lend more to the 
private sector than domestic banks, public credit of foreign banks exceeds private credit.

We also find that profitability of foreign banks is above that of domestic banks. The interest margins of foreign banks are somewhat below that of the domestic banks, non-interest income is higher, while overhead costs are about the same as that of domestic banks. A convergence with respect to the performance of the domestic and the foreign banks can be witnessed in the transition countries.

Finally, the increased participation of foreign banks also gives rise to numerous other questions. For instance, how does the transfer of knowhow and technology occur, and what is its impact upon relative performance? Is the huge foreign bank presence sustainable and what are the implications for financial stability? Which strategies are behind the foreign bank penetration into Central and Eastern Europe and when will credit to the private sector be on a Western European level? These questions may be subject for further research. 
Appendix 1. Description of the database

The database contains two parts:

\section{Part A:}

Aggregated data on the development, structure and performance of the banking systems.

Source: (a) National Central Banks, and (b) International Financial Statistics of the IMF. In case the data conflicted, we opted for those provided by the National Central Banks.

The database includes 15 templates for the period 1990-2000:

1 Deposit money banks assets as percentage of GDP (a) and (b)

2 Private credit by deposit money banks as percentage of GDP (a) and (b)

3 Deposit money bank assets to total financial assets (a) and (b)

$4 \quad$ Foreign bank assets as percentage of GDP (a)

$5 \quad$ Private credit by foreign banks as percentage of GDP (a)

$6 \quad$ Foreign banks assets as share of deposit money banks assets (a)

$7 \quad$ Number of foreign and domestic banks (a)

$8 \quad$ Number of foreign subsidiaries (a)

$9 \quad$ Number of foreign branches (a)

10 Number of banks with foreign participation (a)

11 Return on assets (ROA) of foreign and domestic banks (a)

12 Return on equity (ROE) of foreign and domestic banks (a)

13 Net interest margin of foreign and domestic banks (a)

14 Overhead costs as share of total assets of foreign and domestic banks (a)

15 After tax income (\% of total income) of foreign and domestic banks (a)

\section{Definitions:}

'Deposit money banks' comprises all financial institutions that have 'liabilities in the form of deposits transferable by check or otherwise usable in making payments. 'Assets' refers to total domestic financial intermediation that the respective intermediary performs; see Beck et al. (1999), p.4 (IMF definition).

Assets: see Beck et al. (1999), Appendix, p. 4 (line 22 in IFS). 
Foreign means: At least $50 \%$ of the shares of a bank is foreign owned.

Foreign participation: more than 5\% and less than 50\% foreign owned.

Net interest margin: see Beck et al. (1999).

Overhead costs: see Beck et al. (1999).

\section{Part B:}

Micro data. Parts of the financial statement and balance sheet of all banks recorded in BankScope plus background information of the foreign owner

Source: (a) BankScope database, and (b) annual report, internet, email contact .

The database contains 17 variables for the period 1990-2000:

$\begin{array}{ll}1 & \text { Country name (a) } \\ 2 & \text { Bank name (a) } \\ 3 & \text { Year of establishment (a) } \\ 4 & \text { Domestic or foreign owner (b) } \\ 5 & \text { Country of origin of foreign main-owner (b) } \\ 6 & \text { Greenfield or acquisition (b) } \\ 7 & \text { Country rank (a) } \\ 8 & \text { Total assets (a) } \\ 9 & \text { Total customer loans (a) } \\ 10 & \text { Loans to banks (a) } \\ 11 & \text { Loans to Municipalities / Government (a) } \\ 12 & \text { Return on Average Assets (ROAA) - \% (a) } \\ 13 & \text { Return on Average Equity (ROAE) - \% (a) } \\ 14 & \text { Net interest margin (a) } \\ 15 & \text { Overheads (a) } \\ 16 & \text { Profit before tax (a) } \\ 17 & \text { Net income (a) }\end{array}$


Appendix 2.1. Number of foreign banks according to central banks.

\begin{tabular}{lccccccc}
\hline & 1994 & 1995 & 1996 & 1997 & 1998 & 1999 & 2000 \\
\hline Croatia & & 1 & 5 & 7 & 7 & 13 & 20 \\
Czech Rep. & 22 & 24 & 24 & 25 & 25 & 28 & 27 \\
Estonia & & 1 & 1 & 1 & 1 & 3 & 4 \\
Hungary & 18 & 18 & 28 & 32 & 32 & 32 & 33 \\
Latvia & & 12 & 15 & 16 & 16 & 13 & 13 \\
Lithuania & 0 & 0 & 3 & 5 & 5 & 7 & 9 \\
Poland & 11 & 18 & 25 & 29 & 29 & 39 & 48 \\
Romania & 12 & 15 & 19 & 23 & 23 & 26 & 29 \\
Slovak Rep. & 14 & 18 & 14 & 13 & 10 & 10 & 13 \\
Slovenia & 6 & 6 & 6 & 4 & 3 & 5 & 6 \\
Foreign banks & & 113 & 138 & 155 & 163 & 176 & 202 \\
\% of total banks & & $27.9 \%$ & $34.9 \%$ & $39.2 \%$ & $44.8 \%$ & $50.3 \%$ & $61.0 \%$ \\
\hline Source: Central banks & & & & & & &
\end{tabular}

Source: Central banks

Appendix 2.2. Foreign banks assets as percentage of total bank assets.

\begin{tabular}{lccccccc}
\hline & 1994 & 1995 & 1996 & 1997 & 1998 & 1999 & 2000 \\
\hline Croatia & & $0 \%$ & $1 \%$ & $4 \%$ & $8 \%$ & $41 \%$ & $87 \%$ \\
Czech Rep. & $11 \%$ & $17 \%$ & $20 \%$ & $24 \%$ & $27 \%$ & $40 \%$ & $66 \%$ \\
Estonia & & $2 \%$ & $2 \%$ & $2 \%$ & $90 \%$ & $90 \%$ & $97 \%$ \\
Hungary & $14 \%$ & $19 \%$ & $46 \%$ & $62 \%$ & $61 \%$ & $66 \%$ & $67 \%$ \\
Latvia & & $36 \%$ & $53 \%$ & $72 \%$ & $81 \%$ & $76 \%$ & $78 \%$ \\
Lithuania & $0 \%$ & $0 \%$ & $28 \%$ & $41 \%$ & $52 \%$ & $38 \%$ & $57 \%$ \\
Poland & $3 \%$ & $4 \%$ & $14 \%$ & $15 \%$ & $17 \%$ & $47 \%$ & $69 \%$ \\
Slovak Rep. & $12 \%$ & $19 \%$ & $23 \%$ & $30 \%$ & $30 \%$ & $31 \%$ & $43 \%$ \\
Slovenia & $3 \%$ & $4 \%$ & $5 \%$ & $5 \%$ & $5 \%$ & $5 \%$ & $15 \%$ \\
Average & $7.5 \%$ & $11.2 \%$ & $21.4 \%$ & $28.3 \%$ & $41.2 \%$ & $48.2 \%$ & $64.4 \%$ \\
\hline
\end{tabular}

Source: Central banks 
Appendix 3. Total banks in CEE countries

\begin{tabular}{lcccccc}
\hline & $\begin{array}{c}\text { Bank } \\
\text { Scope }\end{array}$ & $\begin{array}{c}\text { missing } \\
\text { banks } \\
(+)\end{array}$ & $\begin{array}{c}\text { expired } \\
\text { banks }\end{array}$ & $\begin{array}{c}\text { missing } \\
\text { branches }\end{array}$ & $\begin{array}{c}\text { Total : } \\
(-)\end{array}$ & $\begin{array}{c}\text { Total } \\
\text { according to }\end{array}$ \\
\hline Croatia & 42 & 9 & 9 & 1 & 43 & 42 \\
Czech Rep. & 27 & 6 & 10 & 10 & 33 & 40 \\
Estonia & 9 & 1 & 4 & 1 & 7 & 7 \\
Hungary & 29 & 8 & 0 & 1 & 38 & 42 \\
Latvia & 28 & 1 & 9 & 1 & 21 & 22 \\
Lithuania & 13 & 1 & 5 & 4 & 13 & 13 \\
Poland & 50 & 28 & 6 & 3 & 75 & 74 \\
Romania & 26 & 8 & 4 & 8 & 38 & 41 \\
Slovak Rep. & 20 & 2 & 6 & 2 & 18 & 23 \\
Slovenia & 26 & 4 & 7 & 0 & 23 & 25 \\
TOTAL & 270 & 68 & 60 & 31 & 309 & 329 \\
\hline
\end{tabular}

Sources: see Appendix 1. 


\section{References}

Barisitz S., "The Development of the Romanian and Bulgarian Banking Sectors since 1990", Focus on Transition, 1, OeNB, 2001.

Beck, T., A. Demirguc-Kunt, R. Levine, "A New Database on Financial Development and Structure", Policy Research Working Paper, 2146, World Bank, 1999.

Berger, A.N., L.F. Klapper, G.F. Udell, "The ability of banks to lend to informationally opaque small businesses", Journal of Banking and Finance, 25, 2001, pp. 2127-2167.

Berger, A.N., Q. Dai, S. Ongena, D.C. Smith, "To what extent will the banking industry be globalized? A study of bank nationality and reach in 20 European nations", Journal of Banking and Finance, 27, 2003, pp. 383415.

Berger, A.N., R. DeYoung, H. Genay, G.F. Udell, "Globalization of financial institutions: Evidence from cross-border banking performance", in: Brookings-Wharton Papers on Financial Activity, 3, 2000, pp. 23-158.

Bonin, J.P., I. Abel, "Retail Banking in Hungary: A Foreign Affair?”, Wesleyan University, Department of Economics, Mimeo, 2000.

Bonin, J.P., K. Mizsei, I.P. Székely, P. Wachtel, "Banking in Transition Economies, Developing Market Oriented Banking Sectors in Eastern Europe”, Cheltenham: Edward Elgar, 1998.

Brealey, R.A., E.C. Kaplanis, "The determination of foreign banking location", Journal of International Money and Finance, 15, 1996, pp. 577-597.

Buch, C.M., "Opening up for Foreign Banks: How Central and Eastern Europe Can Benefit", Economics of Transition, 5 (2), 1997, pp. 339-336.

Buch, C.M., "Why do banks go abroad? Evidence from German Data", Financial Markets, Institutions \& Instruments, 9 (1), 2000, pp.33-67.

Buch, C.M., G.L. DeLong, "Cross-border bank mergers: What lures the rare animal?” Working Paper Kiel Institute for World Economics, 2001.

Caprio, G., D. Klingebiel, "Episodes of Systemic and Borderline Financial Crises." World Bank Working Paper, July 2002. 
Claessens, S., A. Demirguc-Kunt, H. Huizinga, "How does Foreign Entry Affect Domestic Banking Markets?", Journal of Banking and Finance, 25 (5), 2001, pp.891-991.

Clarke, G., R. Cull, M.S. Martinez-Peria, "Does foreign bank penetration reduce access to credit in developing countries? Evidence from asking borrowers." World Bank Working Paper, September 2001.

DeLong, G.L., "Stockholder gains from focusing versus diversifying mergers", Journal of Financial Economics, 59, 2001, pp. 221-252.

DeYoung, R., D.E. Nolle, "Foreign-owned banks in the US: Earning market share or buying it?" Journal of Money, Credit, and Banking, 28, 1996, pp. 622636.

Dobosiewicz, Z., "Foreign Banks in the Polish Banking System", in E. Miklaszewska (ed.), "Competitive Banking in Central and Eastern Europe”, Jagiellonian University, Krakow, 1995, pp. 97-107.

Du, J., "Why do multinational enterprises borrow from local banks?", Economics Letters, 78, 2003, pp. 287-291.

EBRD, “Transition Report 1998”, Oxford: Oxford University Press, 1998.

EBRD, "Transition Report 2001", Oxford: Oxford University Press, 2001.

ECB, "Financial Sector Development and Convergence in Accession Countries: An Overview”, December 2001.

Focarelli, D., A.F. Pozzolo, "The patterns of cross-border bank mergers and shareholdings in OECD countries", Journal of Banking and Finance, 25, 2001, pp. 2305-2337.

Galac, T., Kraft, E., “What Has Been the Impact of Foreign Banks in Croatia?”, Croatian National Bank, 2000.

Goldberg, L.S., A. Saunders, "The determinants of foreign banking activity in the United States", Journal of Banking and Finance, 5 (1), 1981, pp. 17-32.

Green, C., V. Murinde I. Nikolov, "The Efficiency of Foreign and Domestic Banks in Central and Eastern Europe: Evidence on Economies of Scale and Scope", 2002. 
Haas, R.T.A. de, "Finance, Law and Growth during Transition: A Survey", DNB Staff Reports, 74, The Netherlands Bank, 2002.

Haas, R.T.A. de, I.P.P. van Lelyveld, "Foreign Bank Penetration and Bank Credit Stability in Central and Eastern Europe", Research Series Supervision, 43, The Netherlands Bank, 2002.

Hasan, I., K. Marton, "Development and Efficiency of the Banking Sector in a Transitional Economy: Hungarian Experience", BOFIT Discussion paper, 7, Bank of Finland, 2000.

Iakova, D.M., N.L. Wagner, "Financial Sector Evolution in the Central European Economies: Challenges in Supporting Macroeconomic Stability and Sustainable Growth”, IMF Working Paper, 141, 2001.

Khan, M.S., A.S. Senhadji, "Financial Development and Economic Growth: An Overview", IMF Working Paper, 209, 2000.

King, R.G., R. Levine, "Finance and Growth: Schumpeter Might Be Right", Quarterly Journal of Economics, 108 (3), 1993a, pp. 717-38.

King, R.G., R. Levine, "Finance, Entrepreneurship and Growth: Theory and Evidence", Journal of Monetary Economics, 32 (3), 1993b, pp. 513-42.

Konopielko L., "Foreign Banks Entry into Central and East European Markets: Motives and Activities", Post-Communist Economies, 11 (4), 1999, pp. 463-485.

Kraft, E., D. Tirtiroglu, "Bank Efficiency in Croatia: A Stochastic-Frontier Analysis", Journal of Comparative Economics, 26, 1998, pp. 282-300.

Lensink, R., N. Hermes, “The Impact of Foreign Bank Entry on Domestic Banks: Does Economic Development matter?", 2002.

Levine, R., "Financial Development and Economic Growth: Views and Agenda", Journal of Economic Literature, 35, 1997, pp. 688-726.

Levine, R., N. Loayza, T. Beck, "Financial Intermediation and Growth: Causality and Causes", Journal of Monetary Economics, 46, 2000, 31-77.

Mathieson, D.J., J. Roldos, "The Role of Foreign Banks in Emerging Markets", Paper prepared for the IMF-World Bank Brookings Institution conference on Financial Markets and Development, 19-21 April, 2001, New York. 
Mervart, J., "The Czech Banking Sector in the Period of Convergence to European Union Conditions", Czech National Bank WP, 47, 1996.

Moshirian, F., "International investment in financial services", Journal of Banking and Finance, 25, 2001, pp. 317-337.

Noyer, C., "Banking in the Euro Area", Speech by the Vice-President of the European Central Bank, at the 30th Anniversary of the Association of Foreign Banks' Representatives, Frankfurt, 8 November 2001.

Sabi, M., "Comparative Analysis of Foreign and Domestic Bank Operations in Hungary", Journal of Comparative Economics, 22, 1996, pp. 179-188.

Schardax, F., T. Reiniger, "The Financial Sector in Five Central and Eastern European Countries: An Overview", Focus on Transition, 1, OeNB, 2001.

Scholtens, B., "On the theory of international financial intermediation", De Economist, 140, 1992, pp. 470-487

Scholtens, B. "Financial Regulation and Financial System Architecture in Central Europe”, Journal of Banking and Finance, 24, 2000, pp. 525-553.

Seth, R., D.E. Nolle, and S.K. Mohanty, "Do banks follow their customers abroad?" Financial Markets, Institutions, and Instruments, 7, 1998, pp. $1-25$.

Stanley, T.O., C. Roger, and B. McManis, "The effects of foreign ownership of US banks on the availability of loanable funds to small business", Journal of Small Business Management, 31, 1998, pp. 51-66.

Steinherr, A., "Banking Reforms in Eastern European Countries", Oxford Review of Economic Policy, 13 (2), 1997.

Storf, O., "Foreign Banks in the Transformation Process- Hungary and Poland", Deutsche Bank Research special report, 2000.

Williams, B., "The Defensive Expansion Approach to Multinational Banking: Evidence to Date", Financial Markets, Institutions \& Instruments, 11(2), 2002, pp. 127-203.

Yildirim, H.S., and G.C. Philippatos, "Efficiency of Banks: Recent Evidence from the Transition Economies of Europe - 1993-2000", Working Paper University of Saskatchewan, October 2002. 
Zajc, P., "The effect of foreign bank entry on domestic banks in Central and Eastern Europe", Working Paper University of Ljubljana, November 2002. 


\section{CESifo Working Paper Series}

(for full list see www.cesifo.de)

1034 Maureen Were and Nancy N. Nafula, An Assessment of the Impact of HIV/AIDS on Economic Growth: The Case of Kenya, September 2003

1035 A. Lans Bovenberg, Tax Policy and Labor Market Performance, September 2003

1036 Peter Birch Sørensen, Neutral Taxation of Shareholder Income: A Norwegian Tax Reform Proposal, September 2003

1037 Roberta Dessi and Sheilagh Ogilvie, Social Capital and Collusion: The Case of Merchant Guilds, September 2003

1038 Alessandra Casarico and Carlo Devillanova, Capital-skill Complementarity and the Redistributive Effects of Social Security Reform, September 2003

1039 Assaf Razin and Efraim Sadka, Privatizing Social Security Under Balanced-Budget Constraints: A Political-Economy Approach, September 2003

1040 Michele Moretto, Paolo M. Panteghini, and Carlo Scarpa, Investment Size and Firm's Value under Profit Sharing Regulation, September 2003

1041 A. Lans Bovenberg and Peter Birch Sørensen, Improving the Equity-Efficiency Tradeoff: Mandatory Savings Accounts for Social Insurance, September 2003

1042 Bas van Aarle, Harry Garretsen, and Florence Huart, Transatlantic Monetary and Fiscal Policy Interaction, September 2003

1043 Jerome L. Stein, Stochastic Optimal Control Modeling of Debt Crises, September 2003

1044 Thomas Stratmann, Tainted Money? Contribution Limits and the Effectiveness of Campaign Spending, September 2003

1045 Marianna Grimaldi and Paul De Grauwe, Bubbling and Crashing Exchange Rates, September 2003

1046 Assar Lindbeck and Dennis J. Snower, The Firm as a Pool of Factor Complementarities, September 2003

1047 Volker Grossmann, Firm Size and Diversification: Asymmetric Multiproduct Firms under Cournot Competition, September 2003

1048 Dan Anderberg, Insiders, Outsiders, and the Underground Economy, October 2003

1049 Jose Apesteguia, Steffen Huck and Jörg Oechssler, Imitation - Theory and Experimental Evidence, October 2003 
1050 G. Abío, G. Mahieu and C. Patxot, On the Optimality of PAYG Pension Systems in an Endogenous Fertility Setting, October 2003

1051 Carlos Fonseca Marinheiro, Output Smoothing in EMU and OECD: Can We Forego Government Contribution? A Risk Sharing Approach, October 2003

1052 Olivier Bargain and Nicolas Moreau, Is the Collective Model of Labor Supply Useful for Tax Policy Analysis? A Simulation Exercise, October 2003

1053 Michael Artis, Is there a European Business Cycle?, October 2003

1054 Martin R. West and Ludger Wößmann, Which School Systems Sort Weaker Students into Smaller Classes? International Evidence, October 2003

1055 Annette Alstadsaeter, Income Tax, Consumption Value of Education, and the Choice of Educational Type, October 2003

1056 Ansgar Belke and Ralph Setzer, Exchange Rate Volatility and Employment Growth: Empirical Evidence from the CEE Economies, October 2003

1057 Carsten Hefeker, Structural Reforms and the Enlargement of Monetary Union, October 2003

1058 Henning Bohn and Charles Stuart, Voting and Nonlinear Taxes in a Stylized Representative Democracy, October 2003

1059 Philippe Choné, David le Blanc and Isabelle Robert-Bobée, Female Labor Supply and Child Care in France, October 2003

1060 V. Anton Muscatelli, Patrizio Tirelli and Carmine Trecroci, Fiscal and Monetary Policy Interactions: Empirical Evidence and Optimal Policy Using a Structural New Keynesian Model, October 2003

1061 Helmuth Cremer and Pierre Pestieau, Wealth Transfer Taxation: A Survey, October 2003

1062 Henning Bohn, Will Social Security and Medicare Remain Viable as the U.S. Population is Aging? An Update, October 2003

1063 James M. Malcomson, Health Service Gatekeepers, October 2003

1064 Jakob von Weizsäcker, The Hayek Pension: An efficient minimum pension to complement the welfare state, October 2003

1065 Joerg Baten, Creating Firms for a New Century: Determinants of Firm Creation around 1900 , October 2003

1066 Christian Keuschnigg, Public Policy and Venture Capital Backed Innovation, October 2003 
1067 Thomas von Ungern-Sternberg, State Intervention on the Market for Natural Damage Insurance in Europe, October 2003

1068 Mark V. Pauly, Time, Risk, Precommitment, and Adverse Selection in Competitive Insurance Markets, October 2003

1069 Wolfgang Ochel, Decentralising Wage Bargaining in Germany - A Way to Increase Employment?, November 2003

1070 Jay Pil Choi, Patent Pools and Cross-Licensing in the Shadow of Patent Litigation, November 2003

1071 Martin Peitz and Patrick Waelbroeck, Piracy of Digital Products: A Critical Review of the Economics Literature, November 2003

1072 George Economides, Jim Malley, Apostolis Philippopoulos, and Ulrich Woitek, Electoral Uncertainty, Fiscal Policies \& Growth: Theory and Evidence from Germany, the UK and the US, November 2003

1073 Robert S. Chirinko and Julie Ann Elston, Finance, Control, and Profitability: The Influence of German Banks, November 2003

1074 Wolfgang Eggert and Martin Kolmar, The Taxation of Financial Capital under Asymmetric Information and the Tax-Competition Paradox, November 2003

1075 Amihai Glazer, Vesa Kanniainen, and Panu Poutvaara, Income Taxes, Property Values, and Migration, November 2003

1076 Jonas Agell, Why are Small Firms Different? Managers’ Views, November 2003

1077 Rafael Lalive, Social Interactions in Unemployment, November 2003

1078 Jean Pisani-Ferry, The Surprising French Employment Performance: What Lessons?, November 2003

1079 Josef Falkinger, Attention, Economies, November 2003

1080 Andreas Haufler and Michael Pflüger, Market Structure and the Taxation of International Trade, November 2003

1081 Jonas Agell and Helge Bennmarker, Endogenous Wage Rigidity, November 2003

1082 Fwu-Ranq Chang, On the Elasticities of Harvesting Rules, November 2003

1083 Lars P. Feld and Gebhard Kirchgässner, The Role of Direct Democracy in the European Union, November 2003

1084 Helge Berger, Jakob de Haan and Robert Inklaar, Restructuring the ECB, November 2003 
1085 Lorenzo Forni and Raffaela Giordano, Employment in the Public Sector, November 2003

1086 Ann-Sofie Kolm and Birthe Larsen, Wages, Unemployment, and the Underground Economy, November 2003

1087 Lars P. Feld, Gebhard Kirchgässner, and Christoph A. Schaltegger, Decentralized Taxation and the Size of Government: Evidence from Swiss State and Local Governments, November 2003

1088 Arno Riedl and Frans van Winden, Input Versus Output Taxation in an Experimental International Economy, November 2003

1089 Nikolas Müller-Plantenberg, Japan’s Imbalance of Payments, November 2003

1090 Jan K. Brueckner, Transport Subsidies, System Choice, and Urban Sprawl, November 2003

1091 Herwig Immervoll and Cathal O'Donoghue, Employment Transitions in 13 European Countries. Levels, Distributions and Determining Factors of Net Replacement Rates, November 2003

1092 Nabil I. Al-Najjar, Luca Anderlini \& Leonardo Felli, Undescribable Events, November 2003

1093 Jakob de Haan, Helge Berger and David-Jan Jansen, The End of the Stability and Growth Pact?, December 2003

1094 Christian Keuschnigg and Soren Bo Nielsen, Taxes and Venture Capital Support, December 2003

1095 Josse Delfgaauw and Robert Dur, From Public Monopsony to Competitive Market. More Efficiency but Higher Prices, December 2003

1096 Clemens Fuest and Thomas Hemmelgarn, Corporate Tax Policy, Foreign Firm Ownership and Thin Capitalization, December 2003

1097 Laszlo Goerke, Tax Progressivity and Tax Evasion, December 2003

1098 Luis H. B. Braido, Insurance and Incentives in Sharecropping, December 2003

1099 Josse Delfgaauw and Robert Dur, Signaling and Screening of Workers' Motivation, December 2003

1100 Ilko Naaborg, Bert Scholtens, Jakob de Haan, Hanneke Bol and Ralph de Haas, How Important are Foreign Banks in the Financial Development of European Transition Countries?, December 2003 